\title{
From the earth of Africa: $Q$ research in South Africa
}

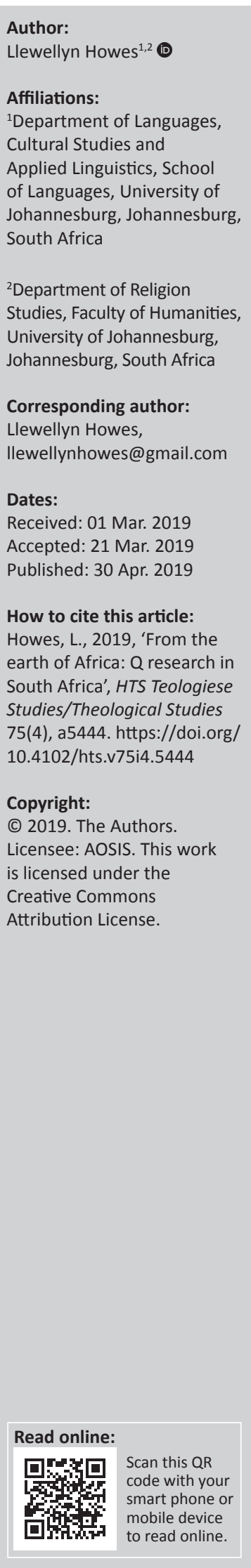

As the title indicates, this article traces the history of $Q$ research in South Africa. It focuses on South African scholars who have made worthwhile contributions to our understanding and knowledge of the Sayings Gospel Q. An attempt is ultimately made to detect some trends in this regard. One significant finding perhaps worth mentioning in the abstract is the undeniable influence of Andries G. van Aarde on Q scholarship in South Africa.

Keywords: Q; Sayings Gospel; South Africa; Research; Trends.

\section{Introduction}

This overview considers research by South African scholars on the Sayings Gospel Q. Given this focus, a number of studies fall outside the current scope of investigation. Firstly, the overview will not include studies of $Q$ texts that focus on their Synoptic form, context or appropriation. ${ }^{1}$ The reason for this is that the current overview wants to focus on studies that concentrate on $Q$ as an independent witness to the early Jesus movement. For obvious reasons, the current study also excludes the publications of foreign scholars in South African journals. ${ }^{2}$ Finally, the study also excludes publications that focus on the Synoptic Problem or the Two-Source Hypothesis and not Q itself. ${ }^{3}$ Apart from considering the contributions of South African scholars to our understanding and knowledge of the Sayings Gospel Q, this article also considers whether or not it is possible to detect any trends in South African scholarship on Q. The presentation is largely chronological, using scholars' first date of publication as an organising principle, but at the same time keeping the discussions of individual scholars separate by treating them in turn.

\section{Patrick Hartin}

Patrick Hartin was born in South Africa and completed his doctoral study on Q there, but later immigrated to Washington, US. Under the supervision of Isak du Plessis at UNISA (the University of South Africa), Hartin was in 1988 the first person to complete a doctoral study on the Sayings Gospel $Q$ in South Africa. The study argued that the letter of James drew from a developed version of $Q$, as it was adapted by the Matthean community, but before it was finally incorporated into the Gospel of Matthew. Arguably the most widely accepted answer to the source-critical question of the relation between James and Q, this doctoral study was published in 1991 as a monograph, and republished in the same form in 2015. An article was also published from the doctoral dissertation, focusing specifically on Q's inaugural sermon and its relation to James (Hartin 1989). In 2000, Hartin contributed to the James Robinson Festschrift, From Quest to Q, focusing on the Woes against the Pharisees in Q 11:39-52 to illustrate that Matthew continued the redactional process started by Q's main redactor when appropriating this pericope. In 2014, he contributed to a volume edited by Alicia Batten and John Kloppenborg on the relation between James and Q. With this contribution, Hartin went beyond mere source-critical questions to explore theological concepts common to James and $Q$, focusing on the concept of 'wholeness'. Throughout this comparison, it is argued that James represents both a development of the Jesus tradition in $Q$ and an intensified theological reflection of that tradition.

Hartin has also focused on questions about $Q$ that are not related to the letter of James. Influenced by Kloppenborg's (1987a) proposed stratification of Q, Hartin argued in 1994 that the proclamation of Jesus was in the first place about a present reality called the kingdom of God, but that the Jesus

1.For example, Botha 1996; Deist 1993; Thirion 1997; Stander 2005; Viljoen 2008; 2009.

2.For example, Bazzana 2014; Foster 2015; Grundeken 2012; Peters 2016; Schmithals 2008; Schröter 1996; Sim 2000; Tripp 2013

3.Engelbrecht (1996), for example, critically considered the contribution of two Markan commentaries that were written from the perspective of the Griesbach hypothesis, finding that these two commentaries fail to explain source-critical issues sufficiently. He remains more convinced by the Two-Source Hypothesis. 
tradition was later appropriated by the early church within a deuteronomistic framework as a message about the imminent, apocalyptic end of the world. Hartin elaborated on the concept of a deuteronomistic development in Q with a subsequent publication on the Sophia logia in Q (1995). After summarising the role of Sophia in Israel's wisdom tradition, Hartin takes a closer look at Q 7:31-35 and Q 11:49-51, the two passages in $Q$ that mention Sophia explicitly. The investigation pays particular attention to the composition and rhetoric of these two passages, but also takes into consideration their relationship to three other $\mathrm{Q}$ texts that probably also allude to Sophia (i.e. Q 10:21-22; 11:31; 13:34$35)$, as well as their relationship to the rest of $Q$ and Israel's wisdom tradition in general. Hartin finds that these sayings about Sophia belong to the second layer of Q, which utters judgements and warnings against Jewish outsiders who oppose the Q people. Experiencing conflict, opposition and persecution from greater Israel, the $Q$ people combined the Sophia and deuteronomistic traditions of ancient Israel in a unique way, so that Sophia became both the agent sending out emissaries and the judge condemning 'this generation' for failing to accept her emissaries and their message.

In 2009, Hartin published an article entitled 'Two Sayings Gospels: The Gospel of Thomas and the Sayings Gospel Q', providing a brief overview of significant research on these two Sayings Gospels. According to him, Thomas originates from the 1st century and provides evidence for a different branch of Christianity. He also maintains that $\mathrm{Q}$ was written between 50 and $70 \mathrm{CE}$, before the fall of the Temple in Jerusalem. The Jesus traditions that originated and circulated in Northern Galilee and Western Syria were probably written down in Antioch. The publication finishes with the following statement:

With an emphasis on asceticism and a countercultural worldview, these two Sayings Gospels provided the foundation within early Christianity for movements such as monasticism and spiritualities that focused on a life directed toward the renunciation of the values of the world.

\section{Jonathan Draper}

Although he has published on many topics related to the New Testament, including the Sayings Gospel Q, Jonathan Draper has focused most extensively on the Didache. ${ }^{4}$ Some of his publications on the Didache discuss $Q$ as well, making it worthwhile to consider some of these publications here. In 1991, Draper published an article that considers the relationship between the Didache and the Gospel of Matthew, both of which, in turn, are closely related to Q. ${ }^{5}$ Three aspects of Draper's understanding of the Didache are important for our purposes. Firstly, Draper (1996) maintains that the Didache derives in large part from existing Jewish tradition:

4.For a concise introduction to the Didache, see Draper (2010).

5.Other publications by Draper also deal with this issue, including most notably his 1996 publication, 'The Jesus Tradition in the Didache', which will also receive consideration below. Not all of these publications are considered here because most of them only treat this issue in passing as part of broader discussions (e.g. Draper 2005:224-225 treat this issue in passing as part of broader discussions (e.
2007:259-260, 2008:174-175, 2010:7-13, 2011a:568).
Thus the core of [Didache] 1-6 is Jewish and pre-Christian (c. 100 B.C.E. to 50 C.E.) and the work as a whole had probably received its present form by the end of the first century C.E. (p. 75)

Secondly, Matthew and the Didache represent the same community, and the direction of influence between these two documents is not one-directional from Matthew to the Didache, but much more complex. Draper (1991) elucidates as follows:

Our contention here is that the Didache is the community rule of the Matthean community, constantly in process of development. Naturally, if this is so, some of its parts will reflect a situation pre-supposed by Matthew's gospel, other parts may reflect a situation after its composition. Only a careful redactional analysis can indicate in which way the influence runs in a specific instance. (p. 372)

Draper goes on to do such a 'careful redactional analysis', the results of which find expression in his 1996 publication, 'The Jesus Tradition in the Didache'. These results entail that Matthew, Luke and the Didache all made independent use of the Sayings Gospel Q, so that neither the Didache nor sections thereof are dependent on the final form of Matthew or Luke. This finding follows in no small way from the observation that ' $t$ ] he material the Didache has in common with Matthew and Luke never includes material these evangelists have drawn from Mark' (Draper 1996:90; emphasis original). ${ }^{6}$ In fact, the influence often seems to run in the other direction, that is, from the Didache, or an earlier version thereof, to Matthew in particular (e.g. Draper 1991:355).

Thirdly, these findings influence Draper's understanding of the relationship between the Didache and the Sayings Gospel Q. To begin with:

the structure of the collected Jesus tradition of the Sayings Gospel $\mathrm{Q}$ in the gospels may reflect a communal Sitz im Leben (life setting) which is preserved in the Didache. (Draper 1995:307)

This quotation is from an article that considers the historical references behind the titles 'apostle', 'prophet', 'teacher', 'bishop' and 'deacon' in the Didache. It is conjectured that the 'apostles' were emissaries from Jerusalem who were replaced after the First Jewish-Roman War by 'prophets' from Galilee. The 'prophets', in turn, were refugees from Galilee seeking asylum after being displaced as a result of the First JewishRoman War (cf. Draper 1998:576). These people brought knowledge of the Jesus tradition with them, which not only secured their entry into and status within this host community, but also led to the Jesus tradition being recorded as an authoritative community rule within the same community. The 'teachers' were:

the agents of this process of collection and textualization into the body of tradition which we now know as the Sayings Gospel Q and its further incorporation into Matthew and Luke's gospels. (Draper 1995:312)

Finally, the 'bishops' and 'deacons' were 'local patrons or officials' who became 'preservers and interpreters of the

6..................................................................................... (1996. form befoit, it seems hard to understand how he culd consistels in their present form beforeit, it seems hard to understand how hecoup consistently " $Q$ " material. Markan material present in Matthew and Luke and only drawn on "Q" material. It would seem a more likely inference that the Didache had access directly to the so-called " $Q$ " material, either in a written or an oral form'. 
textual tradition' (Draper 1995:312). Elsewhere, Draper (1998) summarises:

If I am right in my analysis, then the ' $\mathrm{Q}$ ' tradition first took concrete shape as a body of teaching after the collapse of the Jerusalem community, i.e., $62-80$ C.E. (p. 576)

It should be clear from this overview that Draper views both the Didache and the Sayings Gospel Q as foundational traditions for at least the Matthean community.

This, however, raises questions about the source-critical relationship between the Didache and the Sayings Gospel Q. On the one hand, Draper finds evidence that parts of $Q$ were incorporated into the Didache: 'It appears as if this " $\mathrm{Q}$ " material gradually penetrated an existing community rule [earlier version of the Didache], especially in the catechetical section of chapters 1-6' (Draper 1991:354). Draper (1998:576) also believes that the 'prophets' who joined the Matthean or Didache community from Galilee (see above) played a part in the remoulding of earlier Jesus tradition. On the other hand, Draper finds evidence that (an earlier version of) the Didache was already in existence by the time $Q$ came into the picture, and that this document exerted at least some influence on Q. For example, in his investigation of the saying in Q 10:7 and Didache 13:1, Draper (2005:242-243) finds that the Didache was not dependent on Matthew or Luke when using this proverbial saying, but that it rather provides background information against which this $\mathrm{Q}$ tradition can be understood. A more important example for our purposes is the article Draper published in 2000(a), applying Victor Turner's theory of ritual process and ritual symbol to Chapters $7-10$ of the Didache. These chapters contain prayers that were uttered by insiders when performing baptism and sharing the eucharist. The content of these prayers revolves around 'the concept of incorporation into a new community, an assembly of a renewed kingdom of David/God made known in Jesus the successor of David, the son/child/servant of God' (Draper 2000a:153). When it comes to the significance of Jesus within this community, the emphasis falls on his descent from David and his role as the wisdom of God, not on his death or resurrection. This relates well to Q, which likewise fosters a wisdom Christology and lacks explicit reference to the death and resurrection of Jesus (see also Draper 2007:269, 2010:10, 11) - Q 14:27; 17:33 and Q 13:34-35 notwithstanding (cf. e.g. Smith 2006). From this link between the Didache and the Sayings Gospel Q, as well as earlier findings about the relationship between the Didache and Matthew (see above), Draper (2000a:153) speculates not only that (an earlier version of) the Didache 'could be described as the community rule of the " $\mathrm{Q}$ " community', but also that, in Didache 7-10, 'we may have the eucharistic prayers of the " $\mathrm{Q}$ " community in their simplicity and coherence'.

Apart from historical and source-critical issues, there are some theological and thematic overlaps between the Didache and $\mathrm{Q}$ worth exploring. Some $\mathrm{Q}$ scholars may be pleased to learn that Draper's work on the Didache corroborates some aspects of $\mathrm{Q}$ research in general. For example, his detailed comparison of the Synoptic material with the Didache: seems to confirm the hypothesis that sayings of Jesus were collected and circulated in a more or less fixed form, whether oral or written, before the collection was incorporated into the Gospels as we have them. (Draper 1996:90)

Draper (1996:90-91) continues: 'It may be that these collections

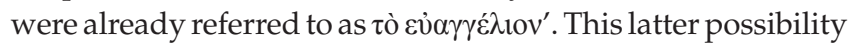
would be welcomed by those who argue that $Q$ should be called a 'Gospel' (e.g. Crossan 1998:31-40; Robinson 1990:viii, 1992:371, 2001:27; see Howes 2015a:89-91). In 2011(b), Draper published an article that applies the economic model of Karl Polanyi to the Didache. One of the article's goals is to determine the extent of overlap between the Didache and $\mathrm{Q}$ when it comes to their economic programmes. Draper (2011b:2) articulates this research question as follows: 'Is the moral economy of " $\mathrm{Q}$ " maintained and still understood in the Didache's "redaction" [...] and how is it further developed?' Draper understands the 'moral economy' of Q mainly along the lines of Horsley's $(1999,2008)$ proposal, according to which Q's Jesus initiated a prophetic movement of socioeconomic and politico-religious renewal among the Galilean peasantry during a time of crisis under Roman rule. According to Draper, the Didache promotes economic practices like hospitality to the needy, general reciprocity and redistribution. Such practices would have established an 'economic safety net' for community members and would have been extremely beneficial to the poor. It was also an alternative to the exploitative economy of the ancient Roman Empire. This economic programme is indeed very similar to the one promoted by Q (see, e.g., Howes 2019; Robinson 1995).

Apart from his work on the Didache, Draper has also produced some publications focusing exclusively on the Sayings Gospel Q. In 1999, Draper contributed three chapters to the book of Richard A. Horsley, Whoever Hears You Hears Me: Prophets, Performance and Tradition in $Q$. The first of these chapters by Draper (1999a:29-45) argues against the hypothesis by Gerd Theissen and others that the early Jesus movement consisted of 'wandering radicals' (Wanderradikalismus), who were supported economically and otherwise by more stable 'community sympathisers' (see also Draper 1998). According to Draper, Theissen's 'wandering radicals' hypothesis is a scholarly construct based on a circular argument ${ }^{7}$ that cannot be applied to the prophets mentioned in the Didache, who seem to have been historic charismatic personalities operating in Syria during the second generation of early Christianity (Draper 1999a:45). There is no evidence to indicate that these prophets were itinerant at all (Draper 1999a:45). Hence, to equate some or all of the $Q$ people with Theissen's 'wandering radicals' would be unfounded and anachronistic.

Draper's second chapter in this volume (1999b:175-194) concentrates more directly on the Sayings Gospel Q. Draper applies his extensive knowledge of orality to Q, emphasising that cognisance of its orally derived nature is crucial to a correct interpretation of the $\mathrm{Q}$ text. This includes, but is not

7.According to Draper, Theissen's hypothesis of Christian origins is largely based on Max Weber's theory of charisma, which, in turn, draws heavily on Adolf von Harnack's description of Christian origins. 
limited to, its use of 'hidden transcript', 'restricted code' and 'metonymic clues' to communicate the 'little tradition' to the peasant class of ancient Galilee. Drawing on the work of, among others, Dell Hymes (1981), Gregory Nagy (1990) and John Miles Foley (1995), who argue that it is possible to identify and recover oral texts and contexts from written material, Draper reconstructs the oral text and context of Q 12:49-59. He is able to not only identify significant oral features in the text of $Q$ 12:49-59, but also reconstruct aspects of its performative context. Although the chapter focuses on $Q$ 12:49-59, the oral features of $Q$ as a whole are also discussed.

Draper's third chapter in the book (1999c:250-259) investigates Q 3:7-9, 16-17, 21-22 and Q 4:1-13 as oral texts (see also Draper 2000b). The analysis is a response not only to those who regard the temptation passage in $Q 4: 1-13$ as a late addition, but also to those who attempt to stratify the Sayings Gospel in the first place, with particular reference to John S. Kloppenborg. According to Draper, the interplay between oral performance and written text in ancient societies is often overlooked by these scholars, specifically in their diachronic analyses of the temptation passage in $Q$. Draper (1999c) explains his method as follows, which corresponds precisely with the method he used when analysing Q 12:49-59 (see above):

Here we will first examine the oral text of each discourse in their mnemonic patterning, balance, parallelism, paratactic construction, and linkage. Then we will analyze the metonymic restricted-code referencing in each discourse as indicators of the register(s) and performance context(s), in particular the field and tenor of the performance. (p. 251)

This examination finds that the two passages relate to each other as the announcement and testing of Jesus as prophet, respectively. This finding is then related to the larger literary context to produce the following sequence for the opening of the Sayings Gospel:

the announcement of the prophet [Q 3:7-9, 16-17, 21-22], the testing of the prophet [Q 4:1-13], the prophet enacting the covenant renewal [Q 6:20-49], the confirmation of the prophet's authority [Q 7:2-9], the prophet fulfilling the age-old longings for renewal [Q 7:18-35], and the prophet commissioning envoys to broaden the movement of renewal of Israel [Q 9:57-10:16] (Draper 1999c:259) ${ }^{8}$

\section{Andries G. van Aarde}

In 1999, Andries van Aarde published an article on the historicity of the figure 'twelve' in relation to the followers of Jesus. The publication compares the Pauline tradition, the Sayings Gospel Q, the Synoptic Gospels, the Gospel of John, Acts and Revelation to develop an intricate map of how the tradition of the 'twelve' developed. As far as Q is concerned, attention is devoted to its stratification, mission discourse and the closing logion about the (twelve) thrones and the twelve tribes of Israel. Drawing on the stratigraphy of $Q$ recent publication (2018:49-72), entitled 'Oral and Literate Contexts for the Sayings Gospel Q'. proposed by John S. Kloppenborg (1987a), Van Aarde argues that Mark made use of $Q$ as it appeared after the addition of the 'main redaction' (or $\mathrm{Q}^{2}$ ). Matthew and Luke made use of $\mathrm{Q}$ in its 'final form' (or $\mathrm{Q}^{3}$ ), after the 'final recension' had already been added. Because the tradition of the 'twelve' appears in Mark but not in Q's formative stratum (or $Q^{1}$ ), this tradition goes back to a pre-Markan source. At some stage during the evolution of $Q$, a list of the 'twelve' became available to those responsible for its production. The $\mathrm{Q}$ list of twelve differed from the pre-Markan one and was later used by the authors of Matthew and Luke. Matthew was influenced by both the Markan and the $Q$ lists when drawing up his list of twelve. As far as the mission discourse is concerned, Van Aarde maintains that the historical Jesus did not say that his followers were sent out. The idea of being 'sent out' was added to Q 10:3 by those responsible for Q's formative stratum to make the logion more relevant to the wider Israelite community. Van Aarde also tables the interesting consideration that the woes against the Galilean towns and associated judgement material were added to the mission discourse during Q's third redactional stage and not during its second redactional stage, as Kloppenborg had originally suggested. The Matthean addition of the 'twelve' to the opening of the mission discourse demonstrates for Van Aarde that the number 'twelve' does not go back to the historical Jesus when referring to his immediate followers. Turning finally to the saying in $Q 22: 28,30$, Van Aarde argues that the redactional activities of Matthew and Luke regarding the 'twelve' thrones of judgement and the 'twelve' tribes of Israel support his view that the figure 'twelve' was introduced by the Jerusalem community after the death of Jesus. Influenced by the post-Easter belief in the resurrection of Jesus, influential male followers of Jesus in the Jerusalem community started the tradition of the 'twelve' to express their conviction that they were the most important apostles and prophets of the 'new Israel' inaugurated by Jesus (see also Van Aarde 2004a). This finding is corroborated by the other traditions that also receive consideration in the article (i.e. Paul, Acts, John and Revelation).

In 2002, Van Aarde published an Afrikaans article on the development of the expression 'Son of Man' in the Jesus tradition. An English version of the article was published 2 years later in Ephemerides Theologicae Lovanienses, featuring the title 'Jesus and the Son of Man: A Shift from the "Little Tradition" to the "Great Tradition"' (Van Aarde 2004b). The contribution argues that the expression 'Son of Man' was used by the historical Jesus when delivering his subversive wisdom to the peasants of the little tradition, referencing humankind in general. Subsequently, the followers of Jesus associated the expression with the apocalyptic Son of Man, using it as a title for Jesus in terms of the scribal great tradition. Van Aarde illustrates this development by using as a case study Q 9:58, the logion about the Son of Man not having anywhere to lay his head. It is argued that this logion originally compared animals and human beings to address the situation of poverty and decline experienced by ancient peasants as a result of Israel's incorporation into the 
Roman Empire. This message was subsequently changed by interpreting the same logion as applying to Jesus in particular, but also warning his followers that they might share in his hardships. This development probably took place during the production of $\mathrm{Q}$, influencing Matthew and Luke. These findings are ultimately related to the broader context of both historical Jesus studies and Q research. Explaining that there is both continuity and discontinuity between the historical Jesus and later developments, Van Aarde argues that the Son of Man tradition reveals a development from an oral, sapiential message delivered by the historical Jesus during his lifetime as part of the 'little tradition', to an apocalyptic, written message delivered by his followers after his death as part of the 'great tradition'.

In 2009, Van Aarde put forward a postcolonial, African reading of the same logion in $Q$ 9:58. Considering the logion on the levels of the historical Jesus, the Sayings Gospel $Q$ and the Gospel of Matthew, Van Aarde discusses the relevance of this saying for the South African context, including especially the reality of severe poverty and criminality in contemporary South Africa. Finally, in 2011, Van Aarde published an article on resurrection in the Synoptic tradition, focusing on the tradition that followers of Jesus will one day sit on thrones, judging the twelve tribes of Israel. A detailed comparison between Matthew 19:27-29, on the one hand, and Q 22:28, 30, Mark 10:28-31 and Luke 22:24-30, on the other, concludes

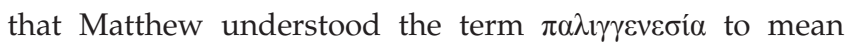
'regeneration' rather than 'resurrection'.

\section{Gerhard Nel (with Andries van Aarde)}

Emanating from a Master's study supervised by Andries van Aarde at the University of Pretoria on ethics in the Sayings Gospel Q, Gerhard Nel copublished an article in 1994 with Van Aarde. It argues that the ethical programme of Jesus was not rooted in imminent or apocalyptic eschatology, but in his sapiential message. Nel continued this line of research under the supervision of Van Aarde, completing in 2001 the second doctoral study to be conducted on $Q$ in South Africa, entitled 'Die etiese uitsprake van Jesus: ApocaliptiesEskatologies of Eties-Eskatologies gegrond?' [The Ethical Statements of Jesus: Grounded in Apocalyptic Eschatology or Ethical Eschatology?]. Building on the 'symbolic eschatology' of Kloppenborg (1987b) and the so-called 'secondary apocalyptic eschatology' of Crossan (1998:260-271), Nel argues that Q's Jesus advocated an ethical programme that understood God's kingdom as a present reality. Nel then applies this 'ethical eschatology' to both the parable of the Mustard Seed in Q 13:18-19 and the pericope about John the Baptist in Q 7:18-20, 31-35. The study finds that the ethical programme of Jesus remains relevant today mainly because it is not apocalyptic or eschatological in the traditional sense. In 2002, Nel and Van Aarde copublished an article on the kingdom of God according to Q, where they argue that the kingdom of God refers in the Sayings Gospel Q to 'an alternative lifestyle in the here and now' (Nel \& Van Aarde 2002:1113). In the same contribution, they draw out the implications of this alternative lifestyle for the church today.
A year later (2003), Nel published an article that considers the history of $Q$ research and defends not only its existence in the first place, but also its sapiential nature and the ability of scholars to distinguish between 'traditional' and 'redactional' material.

\section{Yolanda Dreyer}

Yolanda Dreyer, a friend and long-time colleague of Andries van Aarde at the University of Pretoria, published an article on $Q$ in 2000. The article considers not only the tradition history of $\mathrm{Q}$, but also the Christology of $\mathrm{Q}$ in its final form (after the addition of $\mathrm{Q}^{2}$ and $\mathrm{Q}^{3}$ ), which describes Jesus as the Son of Man, Judge and Son of God. Following Kloppenborg's (1987a) stratigraphy, but not ignoring other form-critical, redaction-critical and tradition-critical scholars like Rudolf Bultmann, Siegfried Schultz, Dieter Lührmann, Dieter Zeller, Burton Mack and Dale C. Allison, Dreyer develops a tradition history of Q. According to Dreyer, the subversive wisdom of $\mathrm{Q}^{1}$ was reinterpreted and expanded by $\mathrm{Q}^{2}$ and $\mathrm{Q}^{3}$ as a result of conflict between the scribes of $Q$ and scribes of the Galilean and Judean administrations. Some of these added traditions derived from Jesus' own historical clashes with the Galilean and Judean administrations, but were reapplied to the $\mathrm{Q}$ people's own circumstances. These were the conditions under which honorary titles were given to Jesus by the $\mathrm{Q}$ scribes. In particular, 'Son of Man' was applied to Jesus as a title in $\mathrm{Q}^{2}$ and 'Son of God' in $\mathrm{Q}^{3}$. Two other important aspects were added to $Q$ during its recension, namely, (1) apocalyptic eschatology, which was introduced during the recension of $\mathrm{Q}^{2}$ and expanded during the creation of $\mathrm{Q}^{3}$, and (2) the mission discourse of $\mathrm{Q}^{2}$ developed a 'universal' perspective during the recension of $Q^{3}$. The ultimate theology of $Q^{3}$ reflects a particular view of Israel's salvation history, which is determined not only by Q's unique deuteronomistic perspective, but also by Q's imminent apocalyptic eschatology - features that were added during Q's recension. Jesus is the decisive figure in this salvation history, although $Q$ does not understand Jesus as a or the Messiah. Instead:

Q sees Jesus as the Son of Man who will come at the end of time, but also as the one who has already been sent by God to fulfill a specific mission in this world. (Dreyer 2000:282)

As 'Son of Man', Jesus will come again to judge and separate between those who accepted his message and those who did not (cf. esp. Q 11:29-32; 13:18-19, 20-21, 28-29, 34-35; 22:30). As 'Son of God', Jesus has a special relationship with the Father, knows his divine will and acts accordingly (cf. esp. Q 4:1-13; 10:22).

\section{Nicholas Taylor}

In recent research, the Galilean provenance of $Q$ has been accepted almost without question. In 2003, Nicholas Taylor challenged this consensus with his article on the provenance of Q. Taylor (2003) considers eight factors that seem to speak against a Galilean provenance of $\mathrm{Q}$ :

(1) the nature and definition of $Q$, and its relationship to other Jesus traditions; (2) the language of Q; (3) scribal skills in rural 
Galilee; (4) the purpose in committing Q to writing; (5) geographical allusions in the reconstructed document; (6) the nature of itinerancy in the mission charge; (7) Israelite traditions and institutions; and (8) Q and primitive Christian kerygma. (p. 283)

The likelihood that $\mathrm{Q}$ was a written Greek document by the time it was incorporated by Matthew and Luke plays a significant role in Taylor's (2003) argumentation:

The cumulative weight of these factors suggests that $Q$ was committed to writing, not in the oral setting of Aramaic speaking rural Galilee, but in a context in which Greek was the language of instruction in the community. (p. 306)

It is important to note that Taylor does not deny that the traditions that make up Q originated in Galilee, but rather argues that the written document used by Matthew and Luke was not written in Galilee. Taylor ultimately suggests a setting outside Palestine, but leaves this as a possibility to be explored by future research.

\section{Markus Cromhout}

In 2005, Markus Cromhout submitted the third doctoral study on $\mathrm{Q}$ to appear in South Africa, also under the supervision of Andries van Aarde, entitled 'The Reconstruction of Judean Ethnicity in $Q^{\prime}$. Taking all the complexities of Judean ethnicity in the 1st century into account, Cromhout argues, firstly, that Galileans were ethnically Judean, and, secondly, that the $\mathrm{Q}$ people identified themselves as ethnically Judean, but abandoned certain identity markers of Judean ethnicity, especially covenantal nomism. The study's most significant contribution is arguably its nuanced explanation of the continuities and discontinuities between traditional Judean ethnicity and Q's modified Judean ethnicity. An article followed in 2006 from this doctoral study, arguing that Q's treatment of the Torah can tell us a lot about the ethnic identity of the Q people. Cromhout follows Kloppenborg's (1987a) stratigraphical model for the most part, arguing that although the first layer is subversive in its approach to the Torah, the redactional material is very conservative about the Torah. It is further proposed that the redactional material was added in part because the $\mathrm{Q}$ people needed to defend its own Judean ethnic identity. Cromhout's doctoral study was published as a monograph in 2007, under the title Jesus and Identity: Reconstructing Judean Ethnicity in Q. In 2015, at a Symposium held in honour of the biblical scholar Wim Weren, Cromhout delivered a paper entitled 'Jesus and his Band of Rebellious Sons: In Conversation with Jerome Neyrey'. After an investigation of Q's content, the paper concludes preliminarily that the $\mathrm{Q}$ people were an itinerant and homeless band of rebellious sons, who had abandoned (with their wives) the traditional family.

\section{Llewellyn Howes}

The fourth doctoral study to appear in South Africa on the Sayings Gospel Q was also supervised by Andries van Aarde. In 2012, Llewellyn Howes submitted his doctoral thesis, arguing that the Sayings Gospel Q depicts Jesus as a teacher of wisdom who subscribed to a non-imminent, non-apocalyptic eschatology. $Q$ therefore supports the sapiential image of Jesus proffered by the Renewed Quest, but not the idea that Jesus was completely non-eschatological. A thoroughly reworked version of the doctoral study was published as a monograph in 2015(a), under the title Judging $Q$ and Saving Jesus: Q's Contribution to the Wisdom-Apocalypticism Debate in Historical Jesus Studies. Based on the exegetical work in previous chapters, the closing chapter of the book lists five aspects of $Q$ to illustrate that it understood Jesus in the first place as a sage: (1) Q's genre, (2) Q's stratigraphy, (3) Q's logia about the Son of Man, (4) Q's logia about the kingdom of God and (5) Q's parables. This does not mean that eschatology is thrown out with the bathwater:

Although Q's Jesus is a teacher of wisdom, he is also portrayed in $Q$ both as appealing to eschatology in support of his sapiential message, and as reaching conclusions about the specific nature of the eschatological end from the content of his wisdom. (2015a:293)

The study further finds that $Q$ 's eschatology is never imminent or urgent, and only sometimes apocalyptic. Despite these nuances, Q's Jesus remains a sage first and foremost: 'Jesus is portrayed in $\mathrm{Q}$ as a sage whose particular brand of wisdom was often eschatological, not as an eschatological prophet whose particular brand of eschatology was sapiential' (2015a:296). The same kind of claim is also made in relation to Q's possible depiction of Jesus as a prophet: 'Jesus is portrayed in $Q$ as a sage whose particular brand of wisdom was often prophetic, not as a prophet whose particular brand of prophecy was sapiential' (2015a:299). Howes (2015a) explains further that:

the wisdom of Q's Jesus is prophetic both in the sense that it makes predictions about the future and in the sense that it takes a stand for the subjugated against the subjugators. (p. 299)

A final feature of the monograph that does not appear in the original dissertation is perhaps worth mentioning, namely, that a genuine attempt is made in Chapter 5 to illustrate how the bridge between the Sayings Gospel $Q$ and the historical Jesus can be traversed.

The mainstay and focus of Howes' research after his doctoral study has been the stratification of Q. From 2013 to 2017, Howes published a series of 11 articles on $Q$ that reconsider the allocation of certain texts to Kloppenborg's formative stratum. Accepting Kloppenborg's (1987a) stratigraphy in its general outline, Howes applies the same criteria to distinguish between Q's formative and redactional layers. The following texts receive consideration: Q 10:21-24 (2013a); Q 11:14-15, 17-20 (2017a); Q 11:33, 34-35 (2013b); Q 12:39-40 (2014a); Q 12:42-46 (2015b, 2015c); Q 12:58-59 (2017b); Q 13:25-27 (2016a); Q 14:16-21, 23 (2015e) and Q 19:12-13, 15-24, 26 (2016b). ${ }^{9}$ Despite their focus on the stratigraphy of $Q$, these articles are also valuable for their exegesis and interpretation of individual Q texts. For example, the article on Q 12:58-59 discusses all of these texts in less detail, but makes the same basic argument (2015d). 
argues that this logion exposes the ancient judicial system for the corrupt and exploitative system that it actually was. The article on Q 13:25 (2016a) holds that this saying has ancient farm workers in mind, exposing their dependency on the hospitality of others for food and shelter. Similarly, the article on Q 14:16-21, 23 (2015e) maintains that this parable advocates general reciprocity and hospitality as a means of feeding the poor. The article on Q 19:12-13, 15-24, 26 (2016b) argues that this parable should be understood as a challenge parable (see Crossan 2012:45-112), challenging the exploitative economic system of antiquity and encouraging people of all social stations to stand up for the most vulnerable in society. ${ }^{10}$

Yet, not all of his publications focus on stratigraphy. In 2013(c), Howes published an article on the Son of Man tradition in the 'final' form of $Q$, finding that $Q$ remembered Jesus using the Son of Man expression both as a non-titular self-reference in the third person and as a reference to Daniel 7:13. In 2014(b), Howes published an article on the saying not to judge in Q 6:37-38 and the widespread ancient belief of psychostasia, which is the idea that one's soul will be weighed after death to determine one's fate in the afterlife. During the same year, Howes (2014c, 2014d) published two articles on the verb 'judge' [ $\kappa \rho i v \omega]$ in Q22:28,30. Taking into consideration the verb's lexical possibilities, literary context in $Q$ and intertextual relationship with the sectarian Dead Sea Scrolls and the pseudepigraphical Psalms of Solomon, Howes argues that it should be understood to mean 'condemn' and not 'liberate', 'redeem' or 'rule', as some other scholars have suggested. Although all of his conference papers cannot be listed here, most of which find expression in his written work anyway, one paper is perhaps worth mentioning as part of the current discussion. In 2014(e), Howes delivered a paper at the Society of Biblical Literature annual meeting in San Diego, arguing that the so-called 'mission discourse' in Q's formative stratum (i.e. Q 10:2-11, 16) was not originally meant to be understood metaphorically, but was rather intended as literal advice for ancient farm workers and day labourers. ${ }^{11}$ Getting back to his written publications, Howes produced an article in 2015(f) that analyses the parable of the Loyal and Wise Slave in Q 12:42-46 against the background of agricultural slavery in the ancient world, taking Jewish, Greco-Roman and Egyptian literature into account. A year later, as part of a special edition of the journal Acta Theologica that focused on the socially disadvantaged and poor in society, Howes (2016c) attempted an interpretation of this parable based on its purported form in Q's first stratum. Essentially, the $Q^{1}$ form of the parable is interpreted as encouraging Jewish leadership to take care of the physical and nutritional needs of their subjects. According to Howes, feeding their subjects was, for Q's formative stratum, the most important task of concurrent Jewish leaders. In the same year, Howes (2016d) published an article arguing that the idea of divine fatherhood was the

10.At the moment, Howes is in the process of reworking these articles to produce monograph on the stratification of $Q$ that will reassess the content, extent and unity of Q's Formative Stratum.

11. Howes is currently in the process of developing this argument further as part of a second doctoral degree. He is currently registered for a PhD in Greek at the University of Johannesburg. The working title of his PhD thesis is 'Ancient Advice for Non-Servile Farm Workers: A Radical Rereading of the So-Called "Mission for Non-Servile Farm Workers: A
Discourse" in the Sayings Gospel Q'. primary paradigm that informed, determined and motivated the alternative socio-ethical programme of Q's formative stratum. The article eventually turns to the notion of 'mutualmothering', contemplating the implications of this alternative socio-ethical programme for women in the $\mathrm{Q}$ movement. In 2018, Howes reconsidered the placement or position of Q 12:58-59 in the Sayings Gospel, boldly claiming that the article 'represents the most extensive treatment of this issue to date' (2018:144). Ultimately, Howes finds that 'the balance of the evidence does indeed support the majority opinion favouring Lukan placement' (2018:170), but not without problematising some of the arguments often made to support Lukan placement in the process. Finally, in 2019, Howes published an article on the message of $Q$ to the peasantry and poor in ancient society. The publication features in an edition of the journal HTS Theological Studies that is dedicated to the South African New Testament scholar Eben Scheffler, 'whose concern for the poor and marginalised shines through in his research' (Howes 2019:11). In this article, the spotlight falls on three specific Q texts, namely, Q 7:24-28, Q 10:5-9 and $Q$ 11:9-13. These texts tell the peasantry and poor that they are important and that they must rely on the hospitality and kindness of others to survive.

\section{Gert Malan}

Many Q scholars regard it as anachronistic to think of the $\mathrm{Q}$ community as a 'church', or to think of the $\mathrm{Q}$ people as 'Christians'. Instead, the $Q$ people seem not to have viewed Jesus as a or the Messiah, not to have acknowledged a chosen group of disciples as their trained leaders, not to have placed much emphasis on the death or resurrection of Jesus (if any), and not to have followed the teachings of Jesus for the sake of post-mortem salvation. As part of a research project on 'Biblical Theology and Hermeneutic' steered by Van Aarde, Gert Malan (2007) asks in his article, 'Die $Q^{1}$ gemeenskap as een van die grondtipes van die kerk in die Nuwe Testament' ['The $\mathrm{Q}^{1}$ Community as Prototype of the Church in the New Testament'], whether those responsible for Q's formative stratum should not, in fact, be viewed as a prototype of the church. Drawing especially on the work of Burton Mack (1993), Malan considers whether the description of the kingdom of God in $\mathrm{Q}^{1}$ brings one close to something akin to 'Christian' thought. The concept and metaphor of God's kingdom is for Malan very important in understanding the self-perception of those responsible for Q's first layer. According to Malan, the Jesus of $\mathrm{Q}^{1}$ was a sage and not an apocalyptic prophet. Drawing on the subversive wisdom of Jesus, the $\mathrm{Q}^{1}$ people understood the kingdom of God as an alternative world and ethic that obliterates conventional wisdom, thereby opening up new possibilities of healing and living. Such an alternative symbolic universe includes social, political, historical, emotional and psychological dimensions, requiring a profound paradigm shift. The $\mathrm{Q}^{1}$ people understood themselves as embodying, living and sharing this alternative symbolic universe. If this is true, a question is introduced about the extent to which the church can be seen as a continuation of this Jesus movement. Malan argues that there is indeed continuity between the 
$\mathrm{Q}^{1}$ community and the Christian church, especially in the sense that both regard themselves as Jesus followers who embody the kingdom of God in this world. Moreover, Malan argues for continuity between the kingdom-of-God concept as understood by the historical Jesus and the $\mathrm{Q}^{1}$ community, respectively. The article closes by challenging the stubborn attachment of the contemporary Christian church to not only apocalyptic eschatology, but also the death and resurrection of Jesus as the only means to salvation. It asks whether an ethical and emotional attachment to the kingdom of God, as the concept was understood by Jesus and his first followers, is not perhaps more important than these doctrinal loyalties. In this way, the $\mathrm{Q}^{1}$ community may be viewed not only as a prototype of the church, but also as a prototype for the church.

\section{Marius $\mathrm{Nel}^{12}$}

Comparing the worldviews of Mark and Q, Marius Nel discovers areas of both overlap and distinctiveness. According to $\mathrm{Nel}$, the most distinctive feature of $\mathrm{Q}$ when compared to Mark is the former's continued commitment to the covenant, the Jerusalem Temple and the Torah. The distinctiveness of the Jewish people over against the greater gentile world remains for the $\mathrm{Q}$ people an important identity marker, even though they have been rejected and perhaps even persecuted by their own kin. For Nel, the greatest area of overlap between Mark and Q is their imminent apocalyptic worldview, despite distinct emphases. Nel (2014) lists a host of features in $\mathrm{Q}$ that he regards as typically apocalyptic, but the following statement probably summarises his assessment best:

$Q$ is permeated with apocalypticism as the product of an early apocalyptic community and describing Jesus as a prophet who commands a certain way of living representing the renewed Israel, battling with the established religious authorities and Satan, and warning of imminent judgment and punishment for evil ones. (p. 90)

\section{Findings}

The aim of this article was not just to summarise research on $Q$ in South Africa, but also to determine whether or not any trends could be identified in this regard. This would indeed seem to be the case. To begin with, most of the scholars considered here accept John Kloppenborg's (sometimes together with Burton Mack's) proposed stratigraphy of Q - if not with regard to each individual text, at least in broad terms. In fact, Kloppenborg's stratigraphy is foundational to all but three of the studies are considered here. Out of these three, Nicholas Taylor and Marius Nel do not oppose his stratigraphy, but focus in their articles on the 'final' $Q$ text. The only scholar who expressly opposes Kloppenborg's stratigraphy is Jonathan Draper, but he nonetheless takes the proposal seriously enough to devote significant space to its refutation.

Those familiar with $Q$ studies will immediately notice that the next few discernible trends in South African scholarship

12.This Marius Nel is affiliated with North-West University in Potchefstroom, South Africa. He is not to be confused with Marius Nel from Stellenbosch University, South Africa. on $\mathrm{Q}$ are directly related to the first. It is not difficult to notice in the research considered here a tendency to award the sapiential traditions in Q chronological and/or substantive priority, which then leads to the conclusion that the historical Jesus was a subversive sage and that apocalyptic, eschatological and/or prophetic traditions were either subsidiary to the wisdom of Jesus or added after Jesus died. Incidentally, those who devote attention to Q's redaction tend to focus specifically on its deuteronomistic and judgemental aspects, viewing these as products of polemical elaboration after Easter. Conversely, those who consider $Q$ in its 'final' form tend to see Q's Jesus as a (social or apocalyptic) prophet. Another observable trend is the particular interest in Q's understanding of God's kingdom, especially on the level of Q's formative stratum. Given this focus, it is no surprise that God's kingdom is viewed by most of these scholars as a present reality. It is also here that one recognises an overlap with Draper. Although he opposes the stratigraphy of $Q$ and does not view Jesus in the first place as a sage, he regards the kingdom of God as a present reality. One may also identify in the research considered here a focus on the expression 'Son of Man'. This focus parallels the earlier trends by maintaining that the historical Jesus used the expression 'Son of Man' in a non-titular, sapiential way, while the early church applied it to the apocalyptic figure in the book of Daniel and associated this figure with Jesus during his Parousia.

The focus on God's kingdom as a present, non-eschatological reality is undoubtedly related to Q's actual content, but it is also directly related to another discernible trend of South African Q scholarship, namely, a tendency to be influenced by the South African context. This is a feature of New Testament scholarship in South Africa more generally. Being in the grips of political, economic and social difficulty, there is a real desire and need for research of all kinds to be contextually relevant. Appreciating and learning from the social, economic and political messages of $Q$, especially its first layer, are therefore important for these researchers. Conversely, the content of $\mathrm{Q}$ lends itself particularly to socio-economic and liberationist African readings, dealing as it does with issues of homelessness, poverty, inequality, hospitality, food, clothing, shelter, survival, reciprocity, healing, exorcism, systemic injustice, exploitation and imperialism. It is therefore not at all surprising to see South African researchers focusing on these aspects of Q. Related to this is the tendency in South African scholarship to not only suppress apocalyptic and eschatological traditions, as we saw, but to also highlight the silence of $\mathrm{Q}$ on the messiahship, death and resurrection of Jesus. It is as if African scholars are petitioning for a tangible, corporeal alternative to the usual theology that placates the poor with 'a pie in the sky when you die'. Ethereal assurances are no longer good enough for a country that faces real-life problems in the here-and-now. This general stance also explains the focus in South African $Q$ research on not only the ethics of Q, but also the relevance of Q's content for the church today. Practical concerns and contemporary relevance seem to be high on the priority list. 
A noticeable shortcoming of $Q$ research in South Africa, however, is the contribution of black scholars. It is impossible to look at the names and surnames listed here without noticing that there are no black scholars contributing to $Q$ scholarship in South Africa at the moment. In this regard, $\mathrm{Q}$ studies are markedly different from other New Testament studies in South Africa. Despite this shortcoming, it is encouraging to see South Africans considering $Q$ from liberationist and postcolonial perspectives. These developments within South African $Q$ research are very promising, and follow in the humanitarian footsteps of Andries van Aarde, including his research focus on issues of inequality and poverty in South Africa, Africa and the world (e.g. Van Aarde 2009, 2016).

A few smaller trends may also be listed here in brief. Although some of the scholars here follow the international trend of assuming a Galilean provenance for $\mathrm{Q}$, there seems to be a tendency among South African scholars to question this consensus. These latter scholars tend to argue that $\mathrm{Q}$ was written outside of Palestine, even if the traditions that make up $Q$ derive from Galilee. Syria is often mentioned as a preferred option, and Hartin narrows it down even further to Antioch. Another minor trend is a focus on the orality of $Q$, which makes sense for a country and continent that has been and continues to be richly blessed with oral traditions. There also seem to be a few favourite texts chosen from $Q$ for analysis by South African scholars. The two most obvious examples are the 'concluding' logion in Q 22:28, 30 and the mission discourse in $Q$ 10:1-16. Predictably, treatments of these texts have included discussions of topics like itinerancy and the renewal of Israel. The latter is, of course, also relevant to the notion of God's kingdom being a present reality, as well as the applicability of $\mathrm{Q}$ to contemporary concerns, including in no small way the social, economic and political renewal of Africa.

The last trend to be highlighted here is not a theme or a text but a person. Like a golden thread running through this article, one name of a South African scholar keeps popping up: Andries G. van Aarde. It would not be an exaggeration to say that his influence has kept $Q$ studies alive in South Africa. Apart from his own research on $Q$, he supervised the doctoral studies by Gerhard Nel, Marcus Cromhout and Llewellyn Howes. He also supervised Master's studies on Q, copublished articles on $\mathrm{Q}$ with other scholars and steered projects that involved research on Q. If $Q$ research lives on in South Africa, it will do so in the work of his students and colleagues, and it will be because of his influence. This is one of the many legacies that Andries will leave behind. The Afrikaans surname 'Van Aarde' literally means 'from the earth', which explains the second level of meaning in the title of this article.

\section{Acknowledgements}

\section{Competing interests}

The author declares that he has no financial or personal relationship(s) that may have inappropriately influenced him in writing this article.

\section{References}

Bazzana, G.B., 2014, 'Violence and human prayer to God in Q 11', HTS Theological Studies 70(1), 8. https://doi.org/10.4102/hts.v70i1.2733

Botha, P.J.J 1996 'Gelykenisse in konteks: Aantekeninge oor Matteus 24:45-25:30', Skrif en Kerk 17(2), 271-291. https://doi.org/10.4102/ve.v17i2.517

Cromhout, M., 2005, 'The reconstruction of Judean ethnicity in $Q$ ', Doctoral dissertation, University of Pretoria, Pretoria, South Africa.

Cromhout, M., 2006, “'We are Judean”! The Sayings Gospel Q's redactional approach to the law', Verbum et Ecclesia 27(3), 794-820. https://doi.org/10.4102/ve. v27i3.186

Cromhout, M., 2007, Jesus and identity: Reconstructing Judean ethnicity in Q, Cascade [Matrix: The Bible in Mediterranean Context 2], Eugene, OR.

Cromhout, M., 2015, 'Jesus and his band of rebellious sons in Q: In conversation with Jerome H Neyrey', paper presented at the Wim Weren symposium on the Gospe of Matthew, p. 22, Pretoria, ZA, 28th January.

Crossan, J.D., 1998, The birth of Christianity: Discovering what happened in the years immediately after the execution of Jesus, HarperSanFrancisco, San Francisco, CA.

Crossan, J.D., 2012, The power of parable: How fiction by Jesus became fiction about Jesus, HarperOne, New York.

Deist, F.E., 1993, 'Die teken van Jona en Jesus as Messias', Skrif en Kerk 14(12), 20-27. https://doi.org/10.4102/ve.v14i1.1273

Draper, J.A., 1991, 'Torah and troublesome apostles in the Didache community' Novum Testamentum 33(4), 347-372. https://doi.org/10.1163/156853691X00123

Draper, J.A., 1995, 'Social ambiguity and the production of text: Prophets, teachers, bishops, and deacons and the development of the Jesus tradition in the community of the Didache', in C.N. Jefford (ed.), The Didache in context: Essays on its text, history and transmission, Brill [NovTSup 77], Leiden, New York \& Köln.

Draper, J.A., 1996, 'The Jesus tradition in the Didache', in J.A. Draper (ed.), The Didache in modern research, pp. 72-91, Brill [Arbeiten zur Geschichte des Antiken Judentums und des Urchristentums 37], Leiden.

Draper, J.A., 1998, 'Weber, Theissen, and "Wandering Charismatics" in the Didache', Journal of Early Christian Studies 6(4), 541-576. https://doi.org/10.1353/earl. 1998.0070

Draper, J.A., 1999a, 'Wandering charismatics and scholarly circularities', in R.A. Horsley \& J.A. Draper (eds.), Whoever hears you hears me: Prophets, performance, and tradition in Q, pp. 29-45, Trinity, Harrisburg, PA.

Draper, J.A., 1999b, 'Recovering oral performance from written text in Q', in R.A Horsley \& J.A. Draper (eds.), Whoever hears you hears me: Prophets, performance, and tradition in Q, pp. 175-194, Trinity, Harrisburg, PA.

Draper, J.A., 1999c, 'The announcement and testing of the prophet', in R.A. Horsley \& J.A. Draper (eds.), Whoever hears you hears me: Prophets, performance, and tradition in Q, pp. 250-259, Trinity, Harrisburg, PA.

Draper, J.A., 2000a, 'Ritual process and ritual symbol in Didache 7-10', Vigiliae Christianae 54(2), 121-158.

Draper, J.A., 2000b, 'Recovering oral tradition fixed in text: The case of Q 3:7-22; $4: 1-13^{\prime}$, in P. Denis (ed.), Orality, memory and the past: Listening to the voices of black clergy under colonialism and apartheid - Papers read at the international conference held at the University of Natal, Pietermaritzburg on 30 June-3 July 1999, pp. 85-111, Cluster, Pietermaritzburg.

Draper, J.A., 2005, 'First-fruits and the support of prophets, teachers, and the poor in Didache 13 in relation to New Testament parallels', in A.F. Gregory \& C.M. Tuckett (eds.), Trajectories through the new testament and the apostolic fathers, pp. 223-243, Oxford University Press, Oxford, NY.

Draper, J.A., 2007, 'The holy vine of David made known to the gentiles through God's servant Jesus: "Christian Judaism" in the Didache', in M. Jackson-McCabe (ed.) Jewish Christianity reconsidered: Rethinking ancient groups and texts, Fortress, Minneapolis, MN

Draper, J.A., 2008, 'Apostles, teachers, and evangelists: Stability and movement of functionaries in Matthew, James, and the Didache' in $\mathrm{H}$. van de Sandt \& J.K. Zangenberg (eds.), Matthew, James, and Didache: Three related documents in their Jewish and Christian settings, SBL [SBL Symposium Series 45], Atlanta.

Draper, J.A., 2010, 'The Didache', in W. Pratscher (ed.), The apostolic fathers: An introduction, Baylor University Press, Waco, TX.

Draper, J.A., 2011a, 'Eschatology in the Didache', in J.G. van der Watt (ed.), Eschatology of the New Testament and some related documents, pp. 567-582, Mohr Siebeck [WUNT 315], Tübingen.

Draper, J.A., 2011b, 'The moral economy of the Didache', HTS Theological Studies 67(1), 10, viewed n.d., from https://hts.org.za/index.php/hts/article/view/907/1557.

Dreyer, Y., 2000, 'The tradition history of the Sayings Gospel Q and the "Christology" of $Q^{3}$, Neotestamentica 34(2), 273-285.

Engelbrecht, J., 1996, 'Challenging the Two-Source Hypothesis: How successful are the commentaries?', Neotestamentica 30(1), 89-101.

Foley, J.M., 1995, The singer of tales in performance: Voices in performance and text Indiana University Press, Bloomington.

Foster, P., 2015, 'The spirituality of Q', HTS Theological Studies 70(1), 8. http://doi.org/ 10.4102/hts.v71i1.2888

Grundeken, M.R.C., 2012, 'Schipperen tussen twee rijken: Q en het Romeinse gezag', HTS Theological Studies 68(1), 8. http://doi.org/10.4102/hts.v68i1.1069

Hartin, P.J., 1988, 'James: A New Testament wisdom writing and its relationship to Q', Doctoral dissertation, University of South Africa (UNISA), Pretoria. 
Hartin, P.J., 1989, 'James and the Q Sermon on the Mount/Plain', in D.J. Lull (ed.), Society of Biblical Literature 1989 seminar papers, pp. 440-457, Scholars Press [SBLASP 28], Atlanta.

Hartin, P.J., 1991 [2015], James and the 'Q' sayings of Jesus, Bloomsbury [JSNTSup 47], London, New York.

Hartin, P.J., 1994, 'The wisdom and apocalyptic layers of the Sayings Gospel Q: What is their significance?', HTS Theological Studies 50(3), 556-582. https://doi.org/ 10.4102/hts.v50i3.2571

Hartin, P.J., 1995, 'Yet Wisdom is justified by her children' (Q 7:35): A rhetorical and compositional analysis of Divine Sophia in Q', in J.S. Kloppenborg (ed.), Conflict and invention: Literary, rhetorical and social studies on the Sayings Gospel $Q$ pp. 151-164, Trinity, Valley Forge, PA.

Hartin, P.J., 2000, 'The woes against the Pharisees (Matthew 23,1-39): The reception and development of $Q$ 11,39-52 within the Matthean community', in J.M Asgeirsson, K. De Troyer \& M.W. Meyer (eds.), From quest to Q: Festschrift James M. Robinson, pp. 265-283. Leuven University Press \& Peeters, Leuven.

Hartin, P.J., 2009, 'Two Sayings Gospels: The Gospel of Thomas and the Sayings Gospel Q', Bible Today 47(3), 167-171.

Hartin, P.J., 2014, 'Wholeness in James and the Q source', in A.J. Batten \& J.S. Kloppenborg (eds.), James, 1 \& 2 Peter, and early Jesus traditions, Bloomsbury [LNTS 478], London.

Horsley, R.A. \& Draper, J.A., 1999, Whoever hears you hears me: Prophets, performance, and tradition in $Q$, Trinity, Harrisburg, PA.

Horsley, R.A., 2008, Jesus in context: Power, people, and performance, Fortress, Minneapolis, MN.

Howes, L., 2012, 'The Sayings Gospel Q within the contexts of the third and renewed quests for the historical Jesus: Wisdom and apocalypticism in the first century' Doctoral dissertation, University of Pretoria, Pretoria.

Howes, L., 2013a, "Blessed are the eyes that see": Revealing the redaction of Q 10:21-24', Ekklesiastikos Pharos 95, 148-172.

Howes, L., 2013b, “Placed in a hidden place": Illuminating the displacement of Q 11:33, 34-35', Neotestamentica 47(2), 303-332.

Howes, L., 2013c, “"To refer, not to characterise": A synchronic look at the Son-of-Man logia in the Sayings Gospel Q', HTS Theological Studies 69(1), 12. http://doi.org/ 10.4102/hts.v69i1.1344

Howes, L., 2014a, 'The householder, the robber and the Son of Man: Reconsidering the redaction of $Q 12: 39-40$ ', Journal of Early Christian History 4(2), 54-75. https://doi.org/10.1080/2222582X.2014.11877304

Howes, L., 2014b, 'Measuring and weighing psychostasia in Q 6:37-38: Intertexts from the Old Testament', HTS Theological Studies 70(1), 9. http://doi.org/10.4102/hts. v70i1.1952

Howes, L., 2014c, 'Condemning or liberating the twelve tribes of Israel?: Judging the meaning of kpivovtec in Q 22:28, 30', Verbum et Ecclesia 35(1), 11. http://doi. meaning of kpivovtes in $\mathrm{a} 22$
org/10.4102/ve.v35i1.872

Howes, L., 2014d, 'Judging the twelve tribes of Israel: Q 22:28, 30 in light of the Psalms of Solomon and the Community Rule', Verbum et Ecclesia 35(1), 11. http://doi. org/10.4102/ve.v35i1.1320

Howes, L., 2014e, 'Advice for farm workers: A radical rereading of the so-called mission discourse', presented on 22 November 2014, during the Society of Biblical Literature (SBL) Annual Meeting (Q Program Unit), San Diego, CA.

Howes, L., 2015a, Judging $Q$ and saving Jesus: Q's contribution to the wisdom apocalypticism debate in historical Jesus studies, AOSIS, Cape Town, viewed n.d. from http://books.aosis.co.za/index.php/ob/catalog/book/21.

Howes, L., 2015b, “'Cut in two", part 1: Exposing the seam in Q 12:42-46', HTS Theological Studies 71(1), 473-477, viewed n.d., from http://www.hts.org.za/ index.php/HTS/article/view/2910.

Howes, L., 2015c, “'Cut in two", part 2: Reconsidering the redaction of Q 12:42-46', HTS Theological Studies 71(1), 478-484, (P.G.R. de Villiers Dedication), viewed n.d., from http://www.hts.org.za/index.php/HTS/article/view/2938.

Howes, L., 2015d, "'Divided against itself"?: Individual maxims and the redaction of Q', Acta Theologica 35(1), 96-114, viewed n.d., from http://apps.ufs.ac.za/ kovsiejournals/default.aspx?article $=2700$

Howes, L., 2015e, "Whomever you find, invite": The parable of the Great Suppe (Q 14:16-21, 23) and the redaction of Q', Neotestamentica 49(2), 321-350, viewed n.d., from http://reference.sabinet.co.za/document/EJC188230.

Howes, L., 2015f, 'Agricultural slavery and the parable of the Loyal and Wise Slave in Q 12:42-46', Acta Classica 58, 70-110, viewed n.d., from http://reference.sabinet. co.za/document/EJC183353.

Howes, L., 2016a, “'I do not know you!": Reconsidering the redaction of Q 13:25-27', Journal of Theological Studies 67(2), 479-506, viewed n.d., from http://jts, oxfordjournals.org/content/early/2016/11/18/jts.flw167.full?keytype=ref\&ijkey= tt8bR6upoXM1rg7.

Howes, L., 2016b, "'Reaping where you did not sow": The parable of the Entrusted Money (Q 19:12-13, 15-24, 26) and the redaction of Q', Journal of Early Christian History 6(2), 18-54, viewed n.d., from http://www.tandfonline.com/eprint/ cUIYY675ctysJ4Z9Drub/full.

Howes, L., 2016c, 'Food for thought: Interpreting the parable of the Loyal and Wise Slave in Q 12:42-44', in D. Francois Tolmie (ed.), Acta theologica supplementum 23: Perspectives on the socially disadvantaged in early Christianity, pp. 110-130, SUN MeDIA, Bloemfontein, viewed n.d., from http://apps.ufs.ac.za/kovsiejournals/ default.aspx?article $=2864$.

Howes, L., 2016d, “'Your Father knows that you need all of this”: Divine fatherhood as socio-ethical impetus in Q's formative stratum', Neotestamentica 50(1), 7-31. https://doi.org/10.1353/neo.2016.0033
Howes, L., 2017a, 'Exorcising the kingdom saying from the Beelzebul story (Q 11:14-15, 17-20)', Journal of Early Christian History 7(1), 28-45, viewed n.d. f $11: 14-15,17-20)$, Journal of Early Christian History 7(1), 28-45, viewed n.d.,
from http://www.tandfonline.com/doi/abs/10.1080/2222582X.2017.1321965.

Howes, L., 2017b, “"Make an effort to get loose": Reconsidering the redaction of Q 12:58-59', Pharos Journal of Theology [formerly, Ekklesiastikos Pharos] 98(electronic version), 1-29, viewed n.d., from http://www.pharosjot.com/current-and-pasteditions.html.

Howes, L., 2018, "'You will not get out of there!": Reconsidering the placement of Q 12:58-59', Neotestamentica 52(1), 141-178, viewed n.d., from http://0-journals. co.za.ujlink.uj.ac.za/content/journal/10520/EJC-fc7657b43.

Howes, L., 2019, 'Q's message to the peasantry and poor: Considering three texts in the Sayings Gospel', HTS Theological Studies 75(3), 1-13. (Eben Scheffler Dedication), viewed n.d., from http://www.hts.org.za/index.php/HTS/article/view/4480.

Hymes, D., 1981, 'In vain I tried to tell you': Essays in Native American ethnopoetics, University of Pennsylvania Press, Philadelphia, PA.

Kloppenborg, J.S., 1987a, The formation of Q: Trajectories in ancient wisdom collections, Fortress [SAC], Philadelphia, PA.

Kloppenborg, J.S., 1987b, 'Symbolic eschatology and the apocalypticism of Q', HTR 80(3), 287-306.

Kloppenborg, J.S., 2018, 'Oral and literate contexts for the Sayings Gospel Q', in C. Heil, G. Harb \& D.A. Smith (eds.), Built on rock or sand? - Q studies: retrospects, introspects and prospects, pp. 49-72, Peeters, Leuven.

Mack, B.L., 1993, The lost Gospel: The book of $Q$ and Christian origins, HarperSanFrancisco, San Francisco, CA.

Malan, G.J., 2007, 'Die $Q^{1}$ gemeenskap as een van die grondtipes van die kerk in die Nuwe Testament', HTS Theological Studies 63(2), 699-715. https://doi.org/ 10.4102 /hts.v63i2.222

Nagy, G., 1990, Pindar's Homer: The lyric possession of an epic past, John Hopkins University Press, Baltimore, MD.

Nel, G.C.J., 2001, Die etiese uitsprake van Jesus: Apokalipties-eskatologies of etieseskatologies gegrond?, Doctoral dissertation, University of Pretoria, Pretoria.

Nel, G.C.J., 2003, 'Die soeke na die betekenis van Q: Inleidende opmerkings oor die geskiedenis van Q-navorsing', HTS Theological Studies 59(2), 475-487. https:// doi.org/10.4102/hts.v59i2.655

Nel, G.C.J. \& Van Aarde, A.G., 1994, 'Die etiek van Jesus in die lig van Q: Eskatologies of wysheidsteologies begrond?', HTS Theological Studies 50(4), 936-952. https:// doi.org/10.4102/hts.v50i4.2592

Nel, G.C.J. \& Van Aarde, A.G., 2002, ‘Die Koninkryk van God by Jesus: 'n Apokaliptieseskatologiese of eties-eskatologiese begrip?', HTS Theological Studies 58(3) 1113-1133. https://doi.org/10.4102/hts.v58i3.597

Nel, M., 2014, 'A comparison between the worldviews of the Gospel of Mark and Q', Journal of Early Christian History 4(2), 76-94. https://doi.org/10.1080/222258 2X.2014.11877305

Peters, J., 2016, 'Gendered activity and Jesus's saying not to worry', Neotestamentica 50(1), 35-52. https://doi.org/10.1353/neo.2016.0034

Robinson, J.M., 1990, 'Foreword', in J.S. Kloppenborg, M.W. Meyer, S.J. Patterson \& M.G. Steinhauser (eds.), Q-Thomas Reader, pp. vii-x, Polebridge, Sonoma, CA.

Robinson, J.M., 1992, 'The Sayings Gospel Q', in F. van Segbroeck, C.M. Tuckett, G. van Belle \& J. Verheyden (eds.). The four Gospels 1992: Festschrift Frans Neirynck, vol. 1, pp. 361-388, Leuven University Press \& Peeters [BETL 100], Leuven, BE.

Robinson, J.M., 1995, 'The Jesus of $Q$ as liberation theologian', in R.A. Piper (ed.), The Gospel behind the Gospels: Current studies on Q, pp. 259-274, Brill [NovTSup 75] Leiden, NL, New York \& Cologne, DE.

Robinson, J.M., 2001, 'The Critical Edition of Q and the study of Jesus', in A. Lindemann (ed.), The Sayings Source $Q$ and the historical Jesus, pp. 27-52, Leuven University Press \& Peeters [BETL 158], Leuven, BE, Paris, FR \& Sterling, VA.

Schmithals, W., 2008, 'Das Messiasgeheimnis und die Spruchquelle', HTS Theological Studies 64(1), 353-375. https://doi.org/10.4102/hts.v64i1.27

Schröter, J., 1996, 'The historical Jesus and the sayings tradition: Comments on current research', Neotestamentica 30(1), 151-168.

Sim, D.C., 2000, 'The sword motif in Matthew 10:34', HTS Theological Studies 56(1), 84-104. https://doi.org/10.4102/hts.v56i1.1698

Smith, D.A., 2006, The post-mortem vindication of Jesus in the Sayings Gospel Q, T\&T Clark [The Library of New Testament Studies 338], London,.

Stander, H.F., 2005, 'The sparrow's fall (Mat 10:29)', HTS Theological Studies 61(4), 1071-1083. https://doi.org/10.4102/hts.v61i4.487

Taylor, N.H., 2003, 'Q and Galilee?', Neotestamentica 37(2), 283-311.

Thirion, W.G., 1997, "n Eksegeties-hermeneutiese ondersoek van die Jonagegewens in Matteus 12:38ev', Skrif en Kerk 18(1), 154-175.

Tripp, J.M., 2013, 'Measuring arguments from order for Q: Regression analysis and a new metric for assessing dependence', Neotestamentica 47(1), 123-148.

Van Aarde, A.G., 1999, 'The historicity of the circle of the Twelve: All roads lead to Jerusalem', HTS Theological Studies 55(4), 795-826. https://doi.org/10.4102/hts. v55i4.1634

Van Aarde, A.G., 2002, 'Die uitdrukking "seun van die mens" in die Jesus-tradisie: 'n Ontwikkeling vanaf ' $n$ landbou-omgewing na die wêreld van skrifgeleerdes', HTS Theological Studies 58(4), 1625-1653. https://doi.org/10.4102/hts.v58i4.710

Van Aarde, A.G., 2004a, 'The earliest Jesus group in Jerusalem', Verbum et Ecclesia 25(2), 711-738. https://doi.org/10.4102/ve.v25i2.295 
Van Aarde, A.G., 2004b, "Jesus and the Son of Man: A shift from the "little tradition" to the "great tradition"', Ephemerides Theologicae Lovanienses 80(4), 423-438. https://doi.org/10.2143/ETL.80.4.542105

Van Aarde, A.G., 2009, '“Foxes' holes and birds' nests" (Mat 8:20): A postcolonial reading for South Africans from the perspective of Matthew's anti-social language', HTS Theological Studies 58(4), 535-544.

Van Aarde, A.G., 2011, 'Regeneration and resurrection in Matthew - Peasants in campo hearing time signals from scribes', HTS Theological Studies 67(3), 7. http:// doi.org/10.4102/hts.v67i3.1012
Van Aarde, A.G., 2016, 'The love for the poor neighbour: In memory of her (Mt 26:6-13)', in D. Francois Tolmie (ed.), Acta Theologica Supplementum 23 . Perspectives on the socially disadvantaged in early christianity, pp. 150-175, SUN MeDIA, Bloemfontein.

Viljoen, F.P., 2008, 'The double call for joy: "Rejoice and be glad" (Mat 5:12), as conclusion of the Matthean macarisms', Acta Theologica 28(1), 205-221.

Viljoen, F.P., 2009, 'A contextualised reading of Matthew 6:22-23: Your eye is the lamp of your body', HTS Theological Studies 65(1), 166-170. https://doi.org/10.4102/ hts.v65i1.152 